\title{
Are Radiotherapy and Chemotherapy Indicated in EBV Positive Lymphoepithelioma-like Gastric Cancer?
}

\author{
Yasemin Benderli Cihan* \\ Kayseri Education and Research Hospital, Department of Radiation Oncology, Turkey \\ *Corresponding author: Yasemin Benderli Cihan, Kayseri Education and Research Hospital, Department of Radiation \\ Oncology, Sanayi District, Ataturk Boulevard, Hastane Street, No:78, 38010 Kocasinan/Kayseri, Turkey
}

\begin{tabular}{|c|c|}
\hline ARTICLE INFO & ABSTRACT \\
\hline Received: 䒄 July 21, 2020 & Citation: Yasemin Benderli Cihan. Are Radiotherapy and Chemotherapy Indicated in \\
\hline Published: 慧 July 30, 2020 & $\begin{array}{l}\text { EBV Positive Lymphoepithelioma-like Gastric Cancer?. Biomed J Sci \& Tech Res 29(2)- } \\
\text { 2020. BJSTR. MS.ID.004769. }\end{array}$ \\
\hline
\end{tabular}

\section{Short Communication}

Gastric cancer (GC) represent a heterogeneous group of tumors in terms of morphological appearance, biological behaviour, molecular sub-origin and histopathological diversity. Rarely seen lymphoepithelioma-like carcinoma (LELC) accunts for nearly $1.1-4.6 \%$ of GCs and the prognosis is good [1]. Among the etiological factors, association of Epstein-Barr virus (EBV) and GC is approximately $10 \%$. This rate is $80 \%$ in LELCs, suggesting that gastric LELC is closely associated with EBV infection [1-3]. So far there is no any satisfactory histological classification of GCs to guide clinical approach and treatment strategies. In 2014, considering previous GC subgrouping studies, The Cancer Genome Atlas Project suggested a new molecular classification. The objective of that study was to define groups showing EBV positivity and to evaluate targeted treatment approaches. However, it could not be possible to determine histopathological implications, and no detailed correlation coul be established with the clinical data in terms of prognosis and biological behaviour [4]. LELCs are usually most commonly in seen men than in women and these tend to be proximally located and have a lower TNM stage. Determination of EBV genome in this group makes lymphoid stroma a remarkable morphological clue [1-3]. Prognosis has found better in EBV associated LELCs. Because of these different characterisics, EBV related and non-related GCs have been proposed to develop through diferent molecular mechanisms [5,6]. In a study Park et al., LELC (n:46) and non-LELC (n:4236) were compared in terms of clinicopathological features and survival. A btter prognosis was reported in LELC advanced stage GCs compared to the other advanced GCs [1]. There are publications in the literature suffesting that, prognosis of LELCs is better without any additional CT and/or RT after surgical treatment $[7,8]$. In conclusion, controlled clinical trials including this group o patients are needed to investigate benefit of immunotherapy and/or targeted treatment methods instead of adjuvant chemoterapy and radiotherapy that have high side effects and low efficiency in LELC.

\section{References}

1. Park S, Choi MG, Kim KM, Kim HS, Jung SH, et al. (2014) Lymphoepithelioma-like carcinoma: a distinct type of gastric cancer. J Surg Res 194(2): 458-463.

2. Min BH, Tae CH, Ahn SM, Kang SY, Woo SY, et al. (2016) Epstein-Barr virus infection serves as an independent predictor of survival in patients with lymphoepithelioma-like gastric carcinoma. Gastric Cancer 19(3): 852-859.

3. Kang BW, Seo AN, Yoon S, Bae HI, Jeon SW, et al. (2016) Prognostic value of tumor-infiltrating lymphocytes in Epstein-Barr virus-associated gastric cancer. Ann Oncol 27(3): 494-501.

4. Comprehensive molecular characterization of gastric adenocarcinoma. Cancer Genome Atlas Research Network. Nature 2014; 513(7517): 202209.

5. Cheng N, Hui DY, Liu Y, Zhang NN, Jiang Y, et al. (2015) Is gastric lymphoepithelioma-like carcinoma a special subtype of EBV-associated gastriccarcinoma? New insight based on clinicopathological features and EBV genome polymorphisms. Gastric Cancer 18(2): 246-255.

6. Cho J, Kang MS, Kim KM (2016) Epstein-Barr Virus-Associated Gastric Carcinoma and Specific Features of the Accompanying Immune Response. J Gastric Cancer 16(1): 1-7.

7. Watanabe H, Enjoji M, Imai T (1976) Gastric carcinoma with lymphoid stroma. Its morphologic characteristics and prognostic correlations. Cancer 38: 232-243.

8. Huang KH, Wang RF, Yang MH, Wu CW, Fang WL, et al. (2013) Advanced gastric cancer patients with lymphoid stroma have better survival than those without. J Surg Oncol 107(5): 523-528. 
ISSN: 2574-1241

DOI: 10.26717/BJSTR.2020.29.004769

Yasemin Benderli Cihan. Biomed J Sci \& Tech Res

(c) (P) This work is licensed under Creative Submission Link: https://biomedres.us/submit-manuscript.php

\begin{tabular}{ll} 
BIOMEDICAL & Assets of Publishing with us \\
RESEARCHES & - Global archiving of articles \\
& - Immediate, unrestricted online access \\
\hline isSN: $2574-1241$ & - Rigorous Peer Review Process \\
\hline
\end{tabular}

